\title{
Evaluation and Implementation Registration of Outpatient with Online Systems at Health Services Center
}

\author{
Imania Halwa El Kariema ${ }^{1}$, \\ Sandu Siyoto ${ }^{2}$, Ratna Wardani ${ }^{3}$ \\ ${ }^{1}$ Master Program of Public \\ Health, IIK STRADA Indonesia \\ ${ }^{2}$ IIK STRADA Indonesia \\ ${ }^{3}$ IIK STRADA Indonesia
}

Email:

elka202@gmail.com

Received: March $6^{\text {th }} 2021$

Accepted : April 12 2021

Published : May $20^{\text {th }} 2021$
ABSTRACT

In an effort to improve the health status of the Indonesian people, the quality of hospital services must always be improved through easy access to health facilities. One way is to use an onlinebased registration service system. This literature review aims to examine some of the problems that occur in online-based registration services. The method used is by conducting a review of various journals on international and online-based registration services in Indonesia, in the 2010-2019 period. Searching for journals using ResearchGate and Google Scholar, the journals that are looking for are journals in the health sector, after several screenings and reviews that match the theme, 22 journals are obtained. The use of an online-based registration service system can reduce the length of patient queues when registering before getting service from a doctor. Several hospitals in Indonesia have used online-based registration services, but there are still many obstacles. This obstacle can occur during the planning process as well as during the service implementation process, for example, namely lack of human resources, missing SOPs, a patient who cannot use a cellphone and a lack of information on patients about the online registration system. The benefits of making this literature review are expected that hospitals that will implement online-based registration services understand and understand what are the factors of obstacles to online registration services so that they are better prepared to avoid these obstacle factors.

Keywords: Evaluation, registration, health services, online systems, registration patient

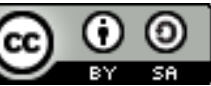

This is an open-acces article distributed under the terms of the Creative Commons Attribution-ShareAlike 4.0 International License.

\section{INTRODUCTION}

In the 1945 Law of the Republic of Indonesia it is written that Health Services is a right for everyone, this statement is something that must be realized because it is part of an effort to improve the health status of the Indonesian people as high as possible (Rilotomo \& Hardjo, 2018). The hospital is one of the centers for individual health services, which is part of the health resources needed to support the implementation of public health efforts (Eka Puspita, 2018). In hospitals or health service centers, problems often appear related to service queues. Queues for services often occur at registration counters. This can arise due to several factors, including the unbalanced number of comparisons between patients registering with service officers so that patients cannot be immediately served for registration (Sukatmi \& Ristani, 2017). Based on the results of the performance assessment of the Outpatient Installation at the Bandung 
Islamic Hospital in the period of the 2nd and 3rd quarter of 2014, the average patient waiting time required more than 60 minutes from the registration process to the examination by a doctor (Susanti, Azis, et al. , 2015). Meanwhile, according to research (Laeliyah \& Subekti, 2017) conducted on outpatients at the Indramayu District Hospital polyclinic, it was found that the waiting time for services was still not going well and was not optimal, namely the average waiting time for patient services was 70.18 minutes.

This is not in accordance with the regulation Kepmenkes 129 / Menkes / SK / II / 2008 concerning Standard of Service. The minimum waiting time set for outpatients is less than or equal to 60 minutes. So that the time recorded from the data above exceeds the time determined by the Ministry of Health (Minister of Health of the Republic of Indonesia, 2008). Based on research (Zhu et al., 2012) conducted at Specialist Outpatient Clinics in Singapore, patients wait for about 5 to 97 minutes while registering to get doctor services. Meanwhile, according to research (Cao et al., 2011) in public hospitals in China, queuing is also a complaint that is often felt by people in China who will take care or treatment at the hospital. Some patients have to queue from the night waiting at the registration place to be able to receive treatment or medication the next day.

Waiting time is the time it takes for a patient to start registering until the patient gets doctor's service. The waiting time is an indicator in the queuing system. There are so many factors that can affect waiting time when registering at the health service counter, one of which is the lack of number of service personnel and the number of patients who will register, so patients have to wait until they can be served by officers. In addition, the lack of doctors providing services at that time made queuing of patients unavoidable (Susanti, Widiyastuti, et al., 2015). As well as the limitation on the number of BPJS Participant patient visits to each doctor, even though we know for ourselves that the average Indonesian people are BPJS participants (Sukatmi \& Ristani, 2017). The use of manual medical record services can also be a factor in the length of time for registration (Solihah \& Budi, 2018).

The hospital registration system is still done manually by means of patients having to queue according to their seat one by one to get a queue number, then after that the patient will be called according to the queue number that has been held to register at the registration officer. The use of such a system can cause queues to increase and the patient's waiting time will be longer. For BPJS participant patients, the most frequent accumulation of queues occurs, some even wait before the queue collection counters are opened by hospital officials (Sukatmi \& Ristani, 2017). In overcoming the buildup of queues and reducing the length of time waiting for patients when registering (Solihah \& Budi, 2018) to get service by doctors, you can do an online-based registration service system (Sukatmi \& Ristani, 2017). Online registration or mobile phone itself is divided into several types, namely via SMS (Short Message Service), WhatsApp, telephone (Eka Puspita, 2018) Website and also those using Android-based applications (Sukatmi \& Ristani, 2017).

Implementing a website-based registration system can effectively reduce patient waiting times and can significantly increase patient satisfaction with the registration process at Xijing Hospital China (Cao et al., 2011). This is in line with research (Susanti, Widiyastuti, et al., 2015), that the waiting time at the Bandung Islamic Hospital registration counter using the SMS / Telephone system service is faster than patients who register directly.

The online registration system is a registration procedure where patients do not need to come directly to the hospital. But by using remote technology facilities, for example by telephone, SMS (Short Message Service), WhatsApp, WEB, or applications (Solihah \& Budi, 2018). Several hospitals have implemented online-based registration service systems, but there are still many hindering factors such as the lack of socialization provided by officers so that patients choose to use manual / button registration and manual / button registration flow is in accordance with the Regional General Hospital dr. Loekmono Hadi Kudus is one of the obstacles in online registration services in addition to patients with elderly people who do not have a cellphone and cellphone number prefer to use manual registration, an error system often occurs during the online registration service process so that the timeliness to reply to delayed messages (Devi \& Dewi, 2019).

The purpose of making this literature review is to find out what are the obstacles that can occur in the application of an online registration system, besides that it can be used as an illustration for hospitals that will start opening registration services with an online system or hospitals that have implemented an online registration system to be better prepared. to avoid and find solutions to these obstacle factors. 
Based on this background, the question arises how to implement an online-based registration service system and how to solve the obstacles that often occur when implementing an online-based registration service system.

\section{MATERIALS AND METHODS}

The method used in making this article review is by searching for journals using ResearchGate and Google Scholar. The journal publication year limit used is 5 years previously, but because the development of international health services is growing rapidly so that the author only finds a few journals that are suitable, the publication year taken is 10 years earlier. The journal that is looking for is a journal in the health sector, in Here the journals that were found were very many, namely 18,334 journals, then filtered with the keyword hospital, obtained 8,193 journals, then continued to search for journals in the hospital registration service section, 1,028 journals were obtained. There are still too many journals for hospital registration services, then journals are searched again with the keyword hospital registration services with an online system, found 392 journals, because the online hospital service system is growing, several international journals also conduct research on online doctor services / application, and the system reminds patient control schedule with the application also exists, but this is not in accordance with the theme of the author's evaluation objectives so that the journal is not used. After the journal was read, 22 journals were selected according to the theme that the author was looking for, namely where the journal included planning, evaluation, processes and obstacles in the online registration service system.

\section{RESULTS}

Online registration procedures usually only apply to old patients, because the patient already has a medical record at the hospital. For patients who will register online, patients usually register 1 day in advance of the day of the examination. In addition, online registration is limited to only 30 perpoli patients per day. In the service, there are often problems with an error computer system that can slow down the registration service process (Rilotomo \& Hardjo, 2018).

Obstacles or constraints that can occur when registering online are 2 categories, namely constraints during service planning and during the service process. Constraints during planning are administrative barriers from a patient who has not been able to use online services or input the identity and others needed during online registration (Rilotomo \& Hardjo, 2018) (Bramantyo \& Hariani, 2018) (Eka Puspita, 2018) (Susanti, Widiyastuti, et al., 2015). The readiness of facilities and infrastructure prior to the implementation of online registration is still lacking (Eka Puspita, 2018) (Haryadi \& Solikhah, 2013). Preparation of new employees, employees needed are not only operator officers who carry out online registration but technician officers are also needed, these employees themselves must also understand and have experience with the tasks to be given and have an educational background that matches their expertise (Wraikat et al. 2017) (Snyder \& Fields, 2006). There is a need for socialization to all employees about the use of the online registration system, so that all employees know how to register online, and can help to promote to the public how to register the latest in the hospital, besides that if someone or a patient asks, they can explained (Wraikat et al., 2017). In addition, there is no appreciation from the hospital for employees who have created online registration innovations or officers involved in online registration so that employees are bored and do not innovate again (Bramantyo \& Hariani, 2018).

While the obstacles during the service process have several causes, namely: according to research (Devi \& Dewi, 2019) (Yu et al., 2013) the lack of socialization provided by officers to patients makes patients still choose to use manual registration by queuing at the registration counter. Patients with elderly who do not understand technology about the use of cellphones and androids, do not have cellphones and cellphone numbers prefer to come early in the morning to register manually (Devi \& Dewi, 2019) (Eka Puspita, 2018). The existence of an error system also often occurs during the online registration service process so that the timeliness of replying to delayed messages (Rilotomo \& Hardjo, 2018) (Devi \& Dewi, 2019). The discipline of officers in registration services is still lacking, so that it can hamper the registration service process (Laeliyah \& Subekti, 2017). In addition, the absence of management administering or making regulations in the form of SOP (Standard Operating Procedure) related to registration services 
hampers the smooth running of online registration services (Laeliyah \& Subekti, 2017) (Devi \& Dewi, 2019) (Eka Puspita, 2018) . According to research (Eka Puspita, 2018) (Haryadi \& Solikhah, 2013) there are limited human resources for online registration officers. This limitation affects the work of the medical record unit because online registration operators are taken from medical record officers so that officers have a double workload, Lack of human resources or officers in the online registration section. Lack of supporting facilities and infrastructure in managing information systems for outpatient registration ( Eka Puspita, 2018) (Haryadi \& Solikhah, 2013). The number of registration patients is still limited, so that daily patients who register overlord and patients must compete to get an examination quota (Rilotomo \& Hardjo, 2018) (White et al., 2011) (Zhu et al., 2012)

Table 1. categories of Obstacle online registration

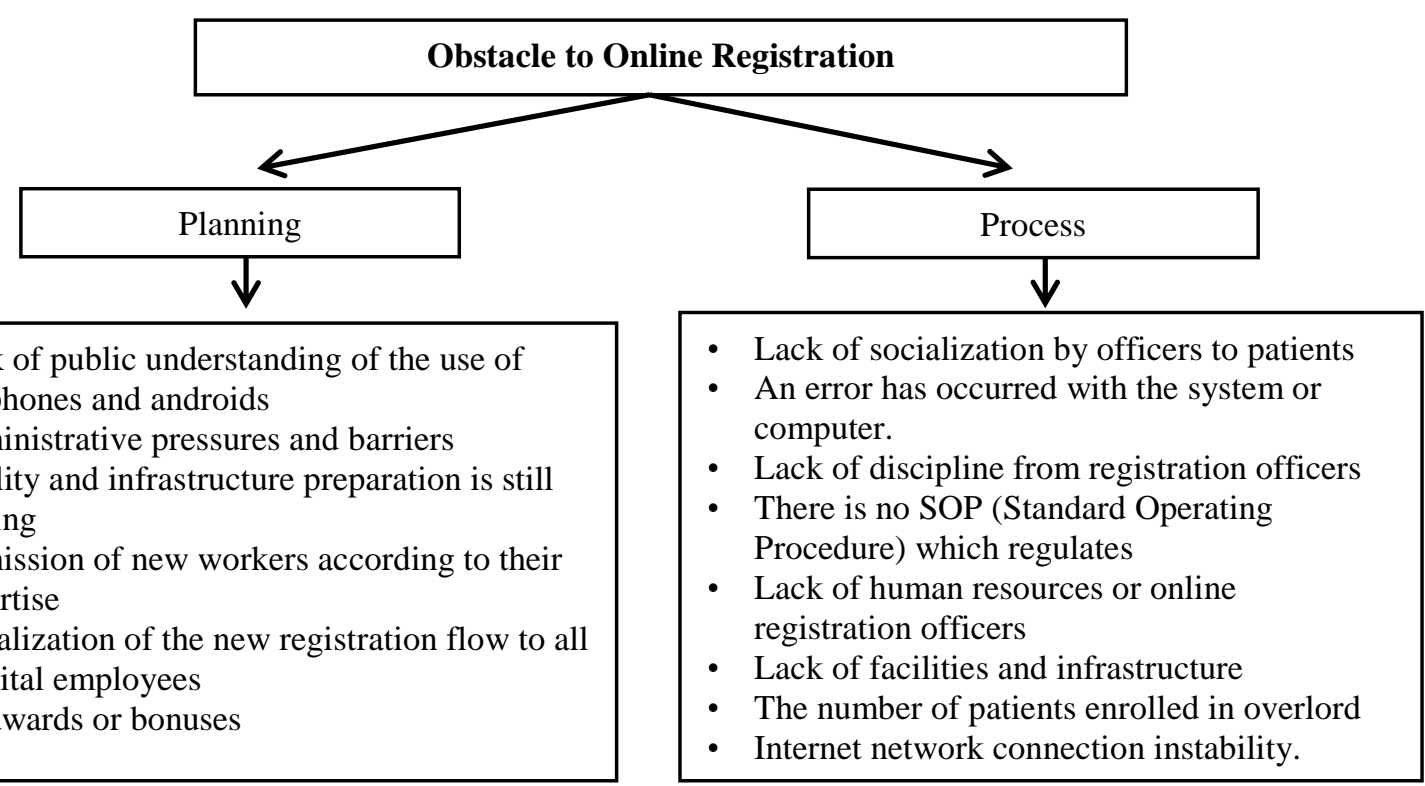

The difference in the length of waiting time for patients who registered directly on the average was 53.56 minutes, while patients who registered online averaged 33.76 minutes before getting service from a doctor. From this long waiting time, it can be seen that online registration has a shorter waiting time than direct registration (Susanti, Azis, et al., 2015). This is in line with the research conducted (Solihah \& Budi, 2018). As much as $16.9 \%$ of the total outpatient registration patients used direct registration and $83.1 \%$ of patients registered online. Patients who prefer to register online are more likely to find it more effective in reducing waiting times and easier online registration than direct registration.

In contrast to research conducted by (Susanti, Widiyastuti, et al., 2015) 58\% of patients still queue directly and the remaining $42 \%$ use online registration. Online registration here uses SMS and telephone systems which are only operated by 1 operator. At the utility level, servers (operators, machines) show very high activity both at direct registration counters (94\%) and sms / telephone counters (93\%). This is because the queuing model used at both counters is a single channel so that there is still an imbalance between the number of service facilities and the number of people who must be served in outpatient installations.

Of the 1594 outpatients who registered online for a period of one month, $72 \%$ of patients preferred to register using SMS, and $28 \%$ of patients used to register using WhatsApp. Because the use of registering via SMS is easier than WhatsApp (Solihah \& Budi, 2018).

\section{DISCUSSION}

The results above show that in the implementation of outpatient registration the waiting time at the online registration counter is faster than the direct registration. This is due to the effectiveness of services at the online registration counter, patients who have registered come to the 
counter only to take the SEP (patient eligibility letter) that has been prepared by the hospital beforehand because during online registration data input and medical records have been prepared in the evening or a day. previously, that was the reason why online registration was done at least 1 day before. In contrast to services at direct registration counters, patients input data and prepare medical records by the new hospital when the patient arrives on the day of the visit, so the process takes longer.

In a hospital that only uses 1 operator in online services it will increase the busyness of the server system, why is that because if there is only 1 server while hundreds or even thousands of patients will register, the server will be overloaded and down due to the large number of incoming SMS and telephone sent, the system slows down, leaving patients waiting for replies or waiting in line to receive calls. Hospitals should pay attention to the ratio of how many patients register with how many servers and operators are needed to avoid system overloads and delays.

There are many types of media used in online registration, the results show that the use of SMS media with WhatsApp has quite a significant difference, where more patients prefer to use the SMS system than WhatsApp. This is because patients or patient guardians who register for outpatient services do not yet have smartphones that provide the WhatsApp program in it, more elderly patients cannot use smartphones. In addition, there are differences in outpatient online registration procedures via WhatsApp and SMS (Short Message Service), namely in registration via WhatsApp, you must attach (upload) a photo of a medical treatment card, referral letter / control warrant, BPJS card (Social Security Administering Body), and KTP (Identity Card).

In the online registration service process, there are many obstacles that can occur, these obstacles are divided into two categories, namely during planning and during the registration process.

When preparing for online registration service planning, there are several requirements that must be implemented so as not to hinder the running of online registration. From the hospital, registration officers and servers must be available in sufficient numbers. Infrastructure such as computers, internet networks, cellphones or smartphones in sufficient numbers, and in prime condition, not using computers or internet networks that are still slow. All hospital staff also need to be socialized and understand how the online registration flow and procedure is. From the patient or the guardian himself, he must also have a cellphone or smartphone as a medium for online registration.

Meanwhile, during the process of online registration services, the hospital must properly, completely and clearly socialize to all patients or guardians about the online registration system and flow, so that the patient or guardian really understands. The infrastructure used also needs to be checked regularly so that there are no obstacles during the service process. All service personnel must be disciplined and carry out services in accordance with the SOPs that have been made by the hospital.

All of the above needs to be done so that during the application process of online registration services can run well and smoothly, besides that the team and online registration service officers must also know possible obstacles that can occur so that it is expected that during the registration process there are obstacles that occur. face any minimum. This is different from research conducted by (Aanestad, Margunn and Vassilakopoulou, 2019). There are 2 factors or obstacles to the online registration system, namely from humans and the system. Human intentions are obstacles caused by human factors, such as patients, service personnel, or their teams.

A patient who cannot input the data that is used as a requirement for online registration can be an obstacle to the online registration process for that patient, or a patient who does not have a cellphone or smartphone cannot register online, service officers who do not understand the online registration procedure do not will be able to explain to patients who will register, if using a manual operator whose officers are not disciplined or lazy to reply to the patient's message, immediately make the patient wait for a long reply from registration, this can make the patient feel less satisfied with the online registration service and the online registration process. hampered. The absence of technicians or experts when there is an error from the WEB system or application so that having to wait for an outside technician can slow down the online registration service process. While the obstacles in the system are errors on the WEB or application, the internet connection or cellphone signal from the patient or registration officer is not good, causing delays in replies or responses so that it can hinder the online registration process.

In this case the problems faced are indeed somewhat similar, but each study has its own category according to the research being carried out, so these constraining factors must be considered so that the online registration process can run smoothly, and patients do not need to wait and queue for a long time. to register before being given health services. 
Of the 22 journals that have been reviewed, $76 \%$ of journals stated that the obstacle for hospitals that did not have SOPs in providing online registration services was the most frequently mentioned barrier. This is very inappropriate, because every service in a hospital must have an SOP (Standard Operating Procedure), the SOP itself is a regulatory system or procedure that is used as a reference when implementing services, if there is no SOP then the service officer can work at will. and if that happens it can cause problems in the future, so that the SOP must be drawn up before the implementation of a service so that the officer can work according to the procedure. The second obstacle that $63 \%$ of the time cited in journals was the client who could not use a mobile phone, did not have a cellphone or telephone number. For elderly patients, some people find it difficult to use cellphones or smartphones because it is a technology that has developed, so it is natural that elderly patients cannot use it. In this case the solution is registration can be assisted by the patient's guardian who can use a cellphone or smartphone if registration is based on whatsapp or application. The third obstacle that is often mentioned as much as $51 \%$ is the number of patients enrolling in an overlord, the number of patients who are always full can be caused by many factors, such as the ratio of staff to patients who is not balanced, too many patients with less staff make the accumulation of patients in the socket. registration, the lack of the number of doctors who provide services with the large number of patients registering can cause piles of queues, service room facilities that are still insufficient making the number of patients served cannot be many at one time but the number of patients who must be provided with health services is large also causes a buildup of queues. When the accumulation of queues occurs a lot at the hospital and patients have to wait a long time before the service makes the patient feel dissatisfied with the quality of hospital services, this can also affect the patient's next visit, so the hospital should better manage the room and sufficient human resources, so as not to there was a buildup of queues.

\section{CONCLUSION}

To provide the best service to the community, the hospital must always pay attention to the quality and quality of its service. In providing online-based registration services that need to be considered are the obstacles that can interfere, there are 2 kinds, namely, obstacles when planning online-based registration services and obstacles during the online-based registration service process.

Patients or guardians who want to register online should be more thorough and prepare the required documents before registering, and for elderly patients who cannot use cell phones, registration should be accompanied by their guardians.

Meanwhile, for hospitals that are starting to apply online registration, it is better not to rush in the implementation process, because there are many preparations that need to be done before opening online-based registration services, namely facilities in the form of computers and cellphones that are suitable and in sufficient numbers, printers, internet connections fast and smooth, special online registration service officers with education in accordance with their work and SOPs must also be made clearly so that officers work with the right guidelines.

The things mentioned above really need to be considered so that the process of running the online registration service can run well and smoothly. Hospitals also need to evaluate and control regularly in the online registration service process so that if any problems are found, they can be resolved immediately.

Based on the results of the review of this article, the author would like to suggest as input for the next research, namely to examine the barriers, weaknesses and advantages of the media used online registration, namely the use of telephone, SMS, Whatsapp, applications and the use of WEB or one of them.

\section{REFERENCES}

Aanestad, Margunn and Vassilakopoulou, P. (2019). Innovation Readiness in Healthcare Information Infrastructures. Scandinavian Conference on Health Informatics, 17th, 61-66.

Snyder, R. A., \& Fields, W. L. (2006). Measuring hospital readiness for information technology (IT) innovation: A multisite study of the Organizational Information Technology Innovation Readiness Scale. Journal of Nursing Measurement, 14(1), 45-55. https://doi.org/10.1891/jnum.14.1.45

Menteri Kesehatan RI. (2011). PERMENKES Nomor 1171 tahun 2011 tentang Sistem Informasi Rumah Sakit. Diunduh pada 1 April 2020 dari https://manajemenrumahsakit.net/wpcontent/uploads/2012/09/bn378-2011.pdf 
Menteri Kesehatan RI. (2008). PERMENKES Nomor 129 Tahun 2008 Tentang Standar Pelayanan Minimal Rumah Sakit. Diunduh pada 15 April 2020 http://manajemenrumahsakit.net/wpcontent/uploads/2012/08/PMK-No-129-tahun-2008-tengan-SPM-RS-lengkap.pdf

Sukatmi, \& Ristani, N. (2017). SISTEM APLIKASI PENGAMBILAN NOMOR ANTRIAN BERBASIS ANDROID PADA RUMAH SAKIT IMANUEL BANDAR LAMPUNG. Jurnal Sistem Informasi Dan Komputer, 5(1).

Eka Puspita. (2018). EVALUASI PENERAPAN PENDAFTARAN ONLINE DI RUMAH SAKIT MATA SOLO. UNIVERSITAS MUHAMMADIYAH SURAKARTA.

Yu, W., Yu, X., Hu, H., Duan, G., Liu, Z., \& Wang, Y. (2013). Use of Hospital Appointment Registration Systems in China: A Survey Study. Global Journal of Health Science, 5(5).

White, D. L., Froehle, C. M., \& Klassen, K. J. (2011). The effect of integrated scheduling and capacity policies on clinical efficiency. Production and Operations Management Society, 20(3).

Rilotomo, P. Y., \& Hardjo, K. (2018). Pelaksanaan Pelayanan Pendaftaran Pasien Rawat Jalan Di Rumah Sakit Umum Daerah Prambanan. UNIVERSITAS JENDERAL ACHMAD YANI YOGYAKARTA.

Susanti, Y., Widiyastuti, E., Dewi, Y., Reza, E., \& Hanifah, I. (2015). Kinerja Sistem Antrian dan Simulasi Model Antrian pada Appointment Registertration System di Instalasi Rawat Jalan Rumah Sakit Al Islam Bandung. Seminar Nasional Penelitian Dan Pengabdian Pada Masyarakat, 1(1), 263-268.

Zhang, M., Zhang, C., Sun, Q., Cai, Q., Yang, H., \& Zhang, Y. (2014). Questionnaire survey about use of an online appointment booking system in one large tertiary public hospital outpatient service center in China. BMC Medical Informatics and Decision Making, 14(1), 1-11. https://doi.org/10.1186/1472-6947-14-49

Laeliyah, N., \& Subekti, H. (2017). Waktu Tunggu Pelayanan Rawat Jalan dengan Kepuasan Pasien Terhadap Pelayanan di Rawat Jalan RSUD Kabupaten Indramayu. Jurnal Kesehatan Vokasional, 1(2), 102. https://doi.org/10.22146/jkesvo.27576

Devi, F. Z., \& Dewi, E. R. (2019). STUDI EVALUASI SISTEM INFORMASI PENDAFTARAN DI RUMAH SAKIT UMUM DAERAH dr. LOEKMONO HADI KUDUS. JKM (Jurnal Kesehatan Masyarakat) Cendekia Utama, 6(2), 74. https://doi.org/10.31596/jkm.v6i2.298

Haryadi, D., \& Solikhah, . (2013). Evaluasi Sistem Informasi Pendaftaran Pasien Rawat Jalan Di Rumah Sakit Umum Pku Muhammadiyah Bantul. Jurnal Kesehatan Masyarakat (Journal of Public Health), 7(2), 55-66. https://doi.org/10.12928/kesmas.v7i2.1013

Zhu, Z., Heng, B. H., \& Teow, K. L. (2012). Analysis of factors causing long patient waiting time and clinic overtime in outpatient clinics. Journal of Medical Systems, 36(2), 707-713. https://doi.org/10.1007/s10916-010-9538-4

Cao, W., Wan, Y., Tu, H., Shang, F., Liu, D., Tan, Z., Sun, C., Ye, Q., \& Xu, Y. (2011). A web-based appointment system to reduce waiting for outpatients: A retrospective study. BMC Health Services Research, 11(1), 318. https://doi.org/10.1186/1472-6963-11-318

Susanti, Y., Azis, Y., \& Kusnadi, D. (2015). Pengaruh Appointment Registration System terhadap Waktu Tunggu dan Kepuasan Pasien. In Global Medical \& Health Communication (GMHC) (Vol. 3, Issue 1, p. 40). https://doi.org/10.29313/gmhc.v3i1.1545

Bramantyo, N. S., \& Hariani, D. (2018). Inovasi Pendaftaran Online di Rumah Sakit Umum Daerah K.R.M.T Wongsonegoro Kota Semarang. Inovasi Pendaftaran Online Di Rumah Sakit Umum Daerah K.R.M.T Wongsonegoro Kota Semarang, 1.

Wraikat, H., Bellamy, A., \& Tang, H. (2017). Exploring Organizational Readiness Factors for New Technology Implementation within Non-Profit Organizations. Open Journal of Social Sciences, 05(12), 1-13. https://doi.org/10.4236/jss.2017.512001

Solihah, A. A., \& Budi, S. C. (2018). Keefektifan Sistem Pendaftaran Online Pasien Rawat Jalan Rsup Dr. Soeradji Tirtonegoro Klaten. Jurnal Manajemen Informasi Kesehatan Indonesia, 6(1), 1. https://doi.org/10.33560/.v6i1.177 